\title{
The Effect of Vlogging on EFL Student Teachers' Teaching Self-efficacy
}

\section{Dr. Samah Zakareya Ahmad Abstract}

This study aimed at investigate the effect of vlogging on EFL student teachers' teaching self-efficacy. A pretest-posttest control group design was adopted, consisting of a control group and an experimental group, each consisting of 12 4th-year EFL student teachers at Faculty of Education, Suez University. A teaching self-efficacy scale was prepared and administered to both groups before the experiment. Participants in the experimental group were trained in vlogging and created a group vlog. For a whole term, they videotaped themselves during Teaching Practice and uploaded the videos to the vlog. They reflected on their teaching performance in the video clips and commented on each others' performance as well. The teaching self-efficacy scale was administered to both groups after the experiment. Statistical analysis revealed a significant improvement in teaching self-efficacy between pretest and posttest for the experimental group while the control group showed no significant improvement. It was recommended that vlogs be used as a method for enhancing EFL teaching self-efficacy.

Key words: Vlogging, EFL Student Teachers, Teaching Self-efficacy

\section{أثر التدوين بالفيديو على كفاءة الذات التدريسية للدي الطلاب المعلمين بشعبة اللغة الإنجليزية أنية}

د/ سماح زكريا أحمد

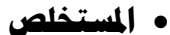

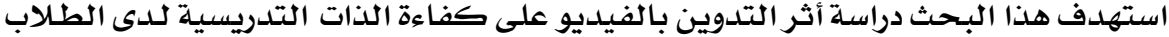

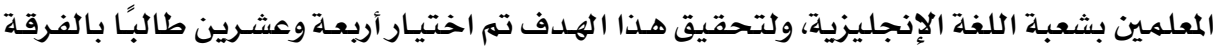

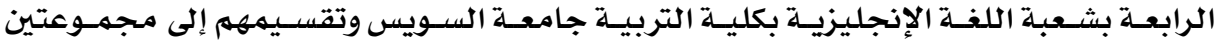

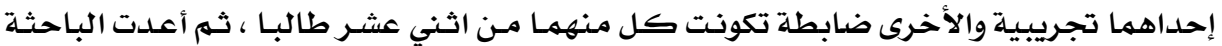

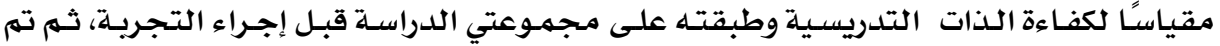

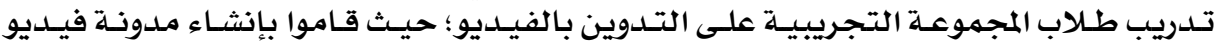

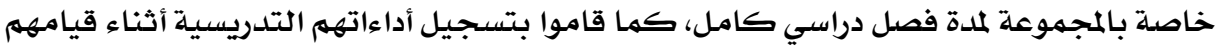

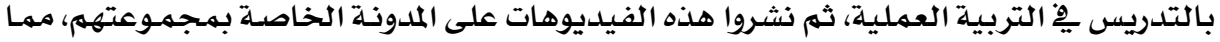

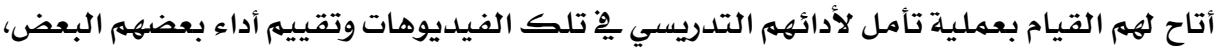

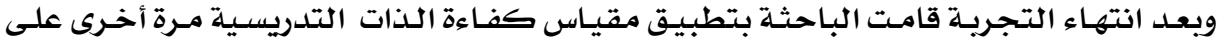

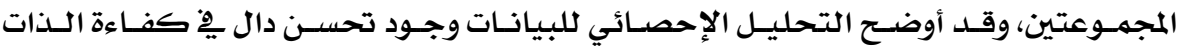

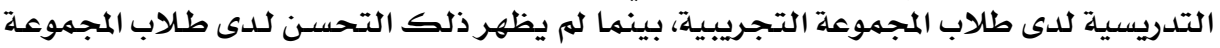

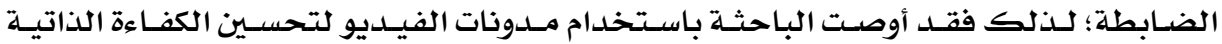

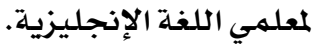
الكلمات المفتاحية: التدوين بالفيديو، الطلاب المعلميلمين بشعبة اللغة الإنجليزية، كفاءة الذات التدريسية اتلمبات

\section{9}




\section{- Introduction and background of the problem}

In Egypt, as in many other countries, educational reform depends not only on improving content, methods, and teaching aids but also on developing teacher's teaching skills and readiness to accept change and to use the improved content and teaching methods. This requires that teachers possess certain beliefs about themselves as well as about the learning and teaching process that depart from the realities of current school practices. One possible reason that makes some teachers not able to change their traditional models while others accept reform and change the environment of their classrooms is that these teachers have different beliefs about teaching and learning. That is, they have different teaching self-efficacy beliefs.

Many frameworks that outline the skills necessary for success in the 21st century emphasize the importance of self-efficacy (Marzano, 2012). Generally, self efficacy refers to an individual's estimation of his/her own capacity (Demirel, 2009) or competence (Scherbaum, CohenCharash \& Kern, 2006) that makes him/her feels effective (Barge, 2012) and provides guidelines for enabling him/her to exercise some influence over how he/she lives (Garvis \& Pendergast, 2011). It is commonly defined as the belief in one's capabilities to achieve a goal or an outcome (Margolis \& McCabe, 2006) and it is thought to be an important moderator between one's knowledge and skills and one's behaviors (Emmer \& Hickman, cited in Giallo \& Little, 2003).

The theoretical foundation of self-efficacy is found in Albert Bandura's social cognitive theory/social learning theory $(1986,2012)$ and self-efficacy theory (1977, 1993 \& 1997). Both theories support the idea that the belief in one's ability to achieve a certain task (selfefficacy) will lead to competent performance of that task (Stripling, Ricketts, Roberts \& Harlin, 2008). According to these theories, a person's perception of self-efficacy with respect to performing a certain task evolves as a result of previous experiences of success and failure in performing similar tasks as well as of having observed other similar people succeed or fail in performing such a task. Here, Bandura (2000) is embracing an integrated perspective for human performance in which social influences operate through psychological mechanisms.

Self-efficacy beliefs can predict performance and have been used in the literature as a measure of such performance, especially when the performance is difficult to measure quantitatively, such as in teaching (Burton, Bamberry \& Harris-Boundy, 2005; Young \& Bippus, 2008). Teaching self-efficacy was viewed in different ways such as: teachers' judgment about his/her capability to produce desired outcomes in student achievement (Brouwers \& Tomic, 2003; Pintrich \& Schunk,

\section{0}


2008; Tschannen-Moran \& Woolfolk Hoy, 2001; Wheatley, 2005; Woolfolk Hoy, 2004; Woolfolk Hoy \& Hoy, 2009), teacher's belief in his/her capability to organize and execute courses of action required to successfully accomplish a specific teaching task in a particular context (Dellinger, Bobbett, Olivier \& Ellett, 2008; Garvis \& Pendergast, 2011; Tschannen-Moran, \& Woolfolk Hoy, 2007; Quinn, 2007), and a combination of teachers' confidence in their ability to teach using effective methods of teaching and the belief that student learning can be influenced when these effective teaching methods are employed (DeChenne, Enochs \& Needham, 2012; Dhatt \& Tiwari, 2013; Stripling et al., 2008; Tschannen-Moran \& Woolfolk Hoy, 2001).

Teaching self-efficacy has been repeatedly associated with positive teaching behaviors and student outcomes (Henson, 2001). Numerous studies have investigated the relation of teaching self-efficacy to important educational outcomes and found that teaching self-efficacy is:

- an important factor in teacher recruitment (Wheeler \& Knobloch, 2006) and retention (Knobloch \& Whittington, 2002; Woolfolk Hoy \& Spero, 2005; Yost, 2006), in teachers' being more resilient across the span of their career (Goddard, Hoy \& Woolfolk Hoy, 2000; Labone, 2004; Wheatley, 2005), in job satisfaction (Skaalvik \& Skaalvik, 2014; Wepner, Krute \& Jacobs, 2009), in the improvement of the personality characteristics of teachers (Yeh, 2006), in reducing teacher burnout and attrition (Swan, Wolf \& Cano, 2011) as well as in teachers' ability to be creative (Scheerens, 2010), and to solve problems (Bangs \& Frost, 2012);

- an attribute of teaching effectiveness (Henson, Kogan \& VachaHaase, 2001; Loreman, Sharma \& Forlin, 2013), motivation (Kaur \& Kaur, 2013), competence (Garvis \& Pendergast, 2011), commitment (Silverman \& Davis, 2009) and confidence (Hines, 2008; Settlage, Southerland, Smith \& Ceglie, 2009);

- influencing teachers' performance in the classroom (Fisler \& Firestone, 2006; Kim, 2009; Onafowora, 2005; Rogalla, 2004; Yoon, 2002) such as: managing classroom (Chambers, Henson \& Sienty, 2001), maintaining discipline (Friedman \& Kass, 2002), adopting a student-focused approach to teaching (Kaye \& Brewer, 2013), using innovative teaching strategies (Silverman \& Davis, 2009), being more likely to take greater intellectual and interpersonal risks in the classroom (Woolfolk Hoy \& Davis, 2005), being ready for managing challenging behaviors (Baker, 2005), and accepting and using technology in the classroom (Chen, 2008; Curts, Tanguma \& Peña,

\section{1}


2008; Haight, 2011; Huntington \& Worrell, 2013; Lumpe \& Chambers, 2001; Maigo \& Mei-yan, 2010; Milbrath \& Kinzie, 2000; Morales, Knezek \& Christensen, 2008; Overbaugh \& Lu, 2008; Niederhauser \& Perkmen, 2008; Pan \& Franklin, 2011; Watson, 2006); and

- correlating positively with students' achievement (Leithwood, 2006; Tschannen-Moran \& Woolfolk-Hoy, 2001), academic performance (Guo, Piasta, Justice \& Kaderavek; 2010), test scores (Hines, 2008), learning motivation (Agbaria, 2013), participation (Gerberry, 2009) satisfaction (Liaw, 2008) and self-efficacy beliefs (Tschannen-Moran \& Hoy, 2001).

Despite the importance of self-efficacy for teachers, many Egyptian teachers have a deficiency in developing their self-efficacy to an adequate level that would enable them to function properly in their teaching. Many studies tackled the problem of the low level of selfefficacy in Egyptian student teachers (e.g., Abdel Rahman, 2012; Ali, 2011; Al-Iraki, 2014; El-Sweedy, 2012; Hassab Allah, 2012; Mohammed, 2010) as well as in-service teachers (e.g., Abdel Aziz, 2010; Al-Aidi, 2011; Mohammed, 1997). Moreover, a teaching selfefficacy scale (Bandura, 2006) was administered by the researcher to a sample of EFL student teachers at Faculty of Education, Suez University. Results confirmed that there is a weakness in those students' teaching self-efficacy. Given the importance of self-efficacy for teachers' professional development, vlogging could prove highly useful to this end.

\section{- Problem and purpose of the study}

The problem of this study was that there were some weaknesses in EFL student teachers' teaching self-efficacy. In order to help these teachers enhance their self-efficacy, the present study attempted to use vlogging.

- Hypothesis of the study

There would be a statistically significant difference $(\alpha \leq 0.05)$ in fourth-year EFL student teachers' teaching self-efficacy between the experimental group and the control group in favor of the experimental group.

- Significance of the study

- Introducing vlogging as a tool that can be used in teacher preparation programs.

- Directing the attention to the necessity to enhance student teachers' teaching self-efficacy.

- Making use of youth's desire to use the Internet and social media.

\section{2}


- Informing teacher educators with respect to how student teachers feel about their teaching self-efficacy, so that more effective courses may be developed to address student teachers' concerns.

- Adding value to scholarly literature with implications for teacher professional development.

- Providing student teachers with an opportunity to transfer the technology knowledge and skills acquired during their study into the learning environment.

\section{- Operational definitions of terms}

The terms below, wherever seen in this study, have the following operational definitions:

Vlogging is EFL student teacher's online publishing videos of his/her authentic in-class teaching, accompanied by self-reflection on his/her teaching performance while other colleagues can evaluate the teaching performance in the videos through comments in written or video form.

Teaching self-efficacy is an EFL student teacher's confidence in his/her ability to: (1) teach effectively; (2) engage students; (3) manage the classroom; (4) socially interact with students, parents and colleagues; (5) cope with changes and challenges; (6) create a positive school climate and (7) adapt education to students' needs.

- Delimitations of the study

The generalization of the results of the present study is delimited to the following:

- Twenty-four fourth-year EFL student teachers at Faculty of Education, Suez University.

- The study lasted for a whole term during which participants were trained as secondary school teachers in some schools in Suez Governorate.

- Measuring teaching self-efficacy was limited to six dimensions: efficacy for classroom instruction; efficacy for student engagement; efficacy for classroom management; efficacy for social interaction with students, parents, and colleagues; efficacy for coping with changes and challenges; efficacy for creating a positive school climate and efficacy for adapting education to students' needs.

\section{- Review of related literature}

Over the past two decades, new technologies have had a profound impact on almost every aspect of people's daily lives (Biggs, 2003) that they could not imagine their lives without them (Mosenson \& Johnson, 2008). These new technologies have also become part of the social and

\section{3}


academic lives of today's students (Lacina, 2008) who spent their entire lives surrounded by and using computers, videogames, digital music players, video cameras, cell phones and all the other toys and tools of the digital age (Prensky, 2001). The evolution of the Internet has presented educators with numerous possibilities for integrating technology into teaching and learning (Haubold \& Kender, 2007; Richardson, 2010).

Web 2.0 technologies have brought to light new ways of understanding and rethinking the Internet (Hung, 2011). Web 2.0 is simply understood as a bottom up organization of tools and activities housed on the Internet (Orr, 2007) that use collaborative approaches to generate and distribute web content characterized by open communication, decentralization of authority and freedom to share and reuse information (Guenter, 2008). A conversational context is established in the new Web 2.0 medium where support for online interactions goes beyond text and includes visual and audio channels and where the model of communication is primarily one of broadcast rather than conversation (Diaz, 2010; Harley \& Fitzpatrick, 2009). Among these innovative Web 2.0 technological possibilities that emerged on the Internet, blogs have experienced phenomenal growth in recent years (Godwin-Jones, 2006; Richardson, 2010).

\section{- $\underline{B l o g s}$}

Over the past few years, Internet blogs, also known as web diaries (Davis, Wright, Coleman \& MacCall, 2007) and informal online chronologies (Abbott, 2010), have emerged as a new communication and publication medium (Shih, 2010) that has grown far faster than most fast-growing Internet trends (Felix \& Stolarz, 2006). A blog is a hierarchy of text, images, media objects and data arranged chronologically and can be viewed in an HTML browser (Winer, 2003). Each new addition of content is called a blog-post or post and appears at the top with old content moving down the blog (Blackall, 2009). Blogs can be considered as online journals where users can update their work in a continuous fashion (Matheson, 2004) as well as discuss issues, share viewpoints, make comments and collaboratively set goals (Efimova \& Fiedler, 2004). They offer an exciting new way to interact and communicate on the Internet (Shih, 2010). Moreover, they encourage feedback from anyone connected to the Internet (Hung, 2011).

Blogs can be used in education as instructors can use them as a medium for such tasks as delivering news, messages and resources as well as encouraging discussion and giving feedback and comments (Weller, Pegler \& Mason, 2005). Moreover, blogs can enable students

\section{4}


to publish their own work, discuss group assignments, peer review each other's work and collaborate on projects (Bloch, 2007). They are valuable for classroom learning because they allow both personal expression and social interaction (Ferdig \& Trammell, 2004).

Blogs, which began as a way to easily post one's thoughts online in print, have evolved to include multimedia capabilities; i.e., a blog is no longer limited to text. Audio and video can also be incorporated (Brazburg, 2007). Many open source content management systems have enabled the inclusion of video content, allowing bloggers to host and administer their own video blogging sites (Kaminsky, 2010). The recent expansion of blogs to video format is often described as vlogs (Pilkington, 2009).

\section{- $\underline{\text { Vlogs }}$}

Vlogs are also called vodcasts, vidcasts (Lacina, 2008), video blogs (Parker \& Pfeiffer, 2005), video-based blogs (Shih, 2010) and multimedia blogs (Papastergiou, Gerodimos \& Antoniou, 2011). People who create vlogs are vloggers and the worldwide community of vlogs and vloggers is the vlogosphere (Brazburg, 2007). The vlog is a series of video files that can be downloaded from the Internet (Llamas-Nistal, Caeiro-Rodríguez \& Castro, 2011). Vlogs' revolutionary potential is based on the fact that they can be made and distributed via the Web by a variety of producers, ranging from big-budget to almost no-budget situations (Mackey, 2005). Vlogs are increasingly popular due to the growth of video-enabled phones and mobile devices (Chan, Chi, \& Chen, 2011; Gronstedt, 2007) which help users organize, store and share video clips for flexible creation of vlogs (Gale \& Kung, 2009).

The vlog is seen by many educationalists as a potentially powerful instructional medium (Johnson, 2005) as well as a suitable teaching tool for this generation of students who grew up during the emergence of the World Wide Web and other digital technologies and are, therefore, regarded as digital natives (Considine, Horton \& Moorman, 2009). The use of instructional vlogs in education has increased rapidly with the advent of video-based educational websites like Kahn Academy $(\mathrm{C}$ and TeacherTube $\mathrm{C}$ (Kay \& Edwards, 2010). Vlog assignments provide opportunities for students to learn both receptive and expressive skills of a language at a comfortable pace, and for instructors to maximize in-class time for increased language use and worthwhile discussions as well as assess student learning anywhere, anytime (Gale \& Kung, 2009).

\section{- Definition of Vlogs}

Attempting to give a definition for vlogs, some researchers focus on the video component of the vlog while others give attention to both the

\section{5}


video component and the blogging component of vlogs. Definitions that focus on the video component include the definition given by Gunelius (2012) who defines a vlog as a series of broadcasts of online video content, the definition of Molyneaux, Gibson, O'Donnell and Singer (2008) who view vlogs as a simple form of online publishing, allowing everyone with web access and simple video production tools to create and post content and the definition of Biel and Gatica-Perez (2010) who consider vlogs as video collections that serve both as an audiovisual life documentary and as a vehicle for communication and interaction on the Internet. In the same line of thought, Mack (2009) defines a vlog as an informal video message that can be used to deliver basic information or to tell a story. Also, the United Nations Environment Program (2014) defines it as a brief and personal video on a particular topic which does not normally entail the use of professional cameras nor is it based on a pre-written script. Moreover, Griffith and Papacharissi (2010) define it as a site where authors post stories and/or information about themselves in the form of video, rather than text.

Definitions of vlogs that focused on both the video and the blogging component of vlogs include the definition of Warmbrodt, Sheng, Hall and Cao (2010) who define vlogs as a new form of blogs where each post is a video. Also, Blackall (2009) defines a vlog as simply a blog that uses video as its primary medium in each post. Another definition is given by Karkoski (2013) defining a vlog as a blog that uses videos. According to him, the video may be posted directly to the site for immediate viewing or it may be downloaded for later viewing on a computer or portable device such as a video iPod. In the same vein, Frobenius (2011) assumes that a vlog is a video sequence similar to a blog that a user (vlogger) shoots of himself/herself talking into a camera and, after optional editing, uploads to the internet, where viewers can rate it and/or leave comments in written or video form.

\section{- Theoretical Foundations of Vlogs}

The attempt to use vlogs in education is based on some theoretical foundations which might include the following:

\section{- Social Constructivism}

Social constructivism, created by Vygotsky, is based on the belief that children's growth is primarily a result of their social interactions with others (Tracey \& Morrow, 2012). Vlogs, facilitating peer feedback and community of practices, could provide the context for social interactions which would, in turn, allow the participating individuals to appropriate and internalize the new knowledge or strategies generated in the online interactions (Bonk \& Cunningham, cited in Hung, 2011). A second key idea in Vygotsky's social constructivism is scaffolding which

\section{6}




\section{Number 55, November ,2014}

refers to the assistance that adults and more competent peers provide during learning episodes (Temple, Ogle, Crawford \& Freppon, 2013). In the vlog-based pedagogy, more experienced vloggers can provide support for less experienced ones. Alternatively, more proficient learners can give less proficient learners feedback, encouragement and guidance (Hung, 2011).

\section{- Media Richness Theory}

Media richness theory, sometimes referred to as information richness theory, was developed by Richard Daft and Robert Lengel (Daft \& Lengel, 1984 \& 1986). Within this theory, text is seen as lean media while video is rich and, hence, more effective for communication (Harley \& Fitzpatrick, 2009). Moreover, the use of multiple media can enrich the communication context and perceived learning (Balaji \& Chakrabarti, 2010). Since vlogs are blogs that primarily feature video shorts instead of text (Dean, 2013), it can be said that vlogs are based on media richness theory.

\section{- Student-Centered Approach}

A student-centered approach to teaching and learning addresses the learner's intellect, social skills, personal experiences and personality (Sweat-Guy \& Buzzetto-More, 2007). In a student-centered class, students do not depend on their teacher all the time neither do they ignore each other. That is, they communicate with each other, help each other and value each other's contributions (Jones, 2007). The use of video technology is helping to change the emphasis to student-centered learning in the classroom. This occurs because students are provided with more options for knowledge processing and also because of a shift in control within the learning environment from the teacher to the student (Reynolds \& Barba, 1996).

\section{- Social Presence Theory}

Social presence theory, introduced by Short, Williams and Christie (1976), highlights the degree to which a medium can represent a communicator to others in terms of acoustic, visual and/or physical indicators. Social presence is the degree to which people feel they are with each other in a collaborative, virtual environment (Biocca, Harms \& Burgoon, 2003). Many researchers believe that video technologies are beneficial for their ability to enhance social presence (Milliken, O'Donnell, Gibson \& Daniels, 2012). Therefore, the vlog is considered among the tools of enhancing social presence (Winter, 2012).

\section{- History of Vlogs}

Vlogs are considered as the platform for Internet delivery of audiovisual media to reach its long-awaited potential (Felix \& Stolarz, 2006). Vlogs gained popularity in 2005 around the launch of the most popular video sharing site, YouTube (Sankar \& Bouchard, 2009) which

\section{7}


attracted millions of users in a dazzling speed during the past few years (Kang et al., 2010) by providing opportunities for social contact (Harley \& Fitzpatrick, 2009). Social connections within YouTube can be initiated by responding to posted videos through subscription or by sending text or video responses. Moreover, the reciprocal practice of responding to others' vlogs with one's own vlog has developed, highlighting the potential of vlogging as a communication medium in its own right (Harley \& Fitzpatrick, 2009). The convergence of mobile phones and digital cameras has enabled a video of an event to be uploaded to the web, where and while it happens (Sankar \& Bouchard, 2009). The growth in the popularity of vlogs is also attributed to the use of video portable media players (Shelley \& Vermaat, 2012). Vlogs have also become increasingly popular as the availability of broadband, high-speed Internet connections has grown (Gunelius, 2012).

\section{- Advantages of Vlogs}

Vlogs are gaining popularity because of their advantages over textbased blogs. The first advantage of vlogs is that they use videos as their principal medium. Naturally, people prefer to see videos than written blogs (Harris, 2008), probably because the movement in videos generally have a high visual impact (Okonkwo, 2010). Studies show that the number of online videos is increasing exponentially and that many people already spend as much (or more) time watching online video as they spend reading online content (Gunelius, 2012). Thanks to services like YouTube and many others, many people are able to publish videos at next to no cost, in hardly no time, and with very little technical ability or expense (Blackall, 2009). Another advantage of vlogs is that they are user-generated. Vloggers engage with videos on several levels; i.e., they are both the encoders and the decoders, both the producers and audience of videos (Molyneaux et al., 2008). Both the teacher and the student alike now have access to a massive library of video that explains and demonstrates seemingly all imaginable techniques and ideas (Blackall, 2009).

Some more advantages of vlogs are mentioned by Bilbao et al., (2009) when they assure that the use of vlogs develops in students the opportunity to: (a) read, watch and listen to the information in any format for gathering knowledge; (b) collaborate with others to enlarge and deepen their knowledge and (c) use technology to create new knowledge as well as organize and present knowledge. Another set of advantages of vlogs include: offering students visual representation, relief from time constraints, self-evaluation, wider audience, peer learning and technical capability (Hung, 2011). Moreover, learners using vlogs become highly motivated and engaged in active

\section{8}


metacognitive learning as well as become involved in teamwork and communication understandings (Litchfield, 2010).

\section{- Challenges of Vlogs}

With the explosive growth of vlogs worldwide, several challenges are posed for vlogging technology (Gao, Tian, Huang \& Yang, 2010). For example, vlogs need a lot of server space as well as a lot of time to process and upload video files and some people can become impatient when loading some vlogs (Harris, 2008). The challenges of vlogs also involve technical difficulties, affective interferences and weak linkage to real-time communication (Hung, 2011).

In the same vein, Belek (2013) mentions some challenges related to vlogging. These challenges included: technical challenges (e.g., adequate lighting and sound as well as proper software), performance challenges (e.g., the vlogger's feeling uncomfortable talking to the camera), and content challenges (e.g., the vlogger's desire to make sure his/her message gets across clearly might push him/her to record the video several times). Moreover, Gao et al. (2010) refer to four challenges that cover most of the important problems and aspects related to the current and future vlogging technology. The first challenge is related to basic supporting infrastructure and techniques which include network bandwidth and media storage. The second challenge of vlogging is mostly about what multimedia technology could give to vlogging and vice versa. The third challenge is related to potential copyright, moral and legal issues. The fourth challenge of vlogging is related to the spawning of incentive applications.

\section{- Vlogs and Teaching Self-efficacy}

Given that the use of vlogs is still a fairly recent development, it is not surprising that little scholarly research has thus far been done on the use of this medium (Chan et al., 2011; Griffith \& Papacharissi, 2010). There are as yet no empirically supported insights into the effect of vlogging on teachers' teaching self-efficacy. Consequently, the area regarding the effect of vlogging on student teachers' teaching selfefficacy has not been addressed. Therefore, the researcher decided to tackle this issue in the present study.

\section{- Method}

\section{- Design}

A pretest-posttest control group design was adopted, consisting of a control group and an experimental group, each consisting of 12 fourthyear EFL student teachers at Faculty of Education, Suez University. All participants were pretested on teaching self-efficacy before the treatment and then posttested after it.

\section{9}




\section{- Participants}

Twelve fourth-year EFL student teachers at Faculty of Education, Suez University, volunteered to be in the experimental group. Other 12 participants in the same class constituted the control group. All participants spent at least 11 years learning EFL. They all ranged between 19-23 years of age.

\section{- Instrument}

Teaching Self-efficacy Scale (TSS) that aimed to measure participants' teaching self-efficacy before and after the experiment was developed through a review of existing literature on teaching selfefficacy in addition to surveys related to teacher self-efficacy such as: Bandura's (2006) Teacher Self-Efficacy Scale, Balam's (2006) Teaching Appraisal Inventory, Dhatt and Tiwari's (2013) Self-efficacy Scale for Student Teachers, Friedman and Kass' (2002) Pre-service Teachers' Self-Efficacy Questionnaire, Gibson and Dembo's (1984) Teacher Efficacy Inventory, Siwatu's (2007) Pre-service Teachers' Culturally Responsive Teaching Self-efficacy Scale, Skaalvik and Skaalvik's (2007) Norwegian Teacher Self-Efficacy Scale as well as Ohio State Teacher Efficacy Scale developed by Tschannen-Moran and Woolfolk Hoy (2001). This review resulted in the specification of seven dimensions of self-efficacy: efficacy for classroom instruction; efficacy for student engagement; efficacy for classroom management; efficacy for social interaction with students, parents and colleagues; efficacy for coping with changes and challenges; efficacy for creating a positive school climate and efficacy for adapting education to students' needs. Under each dimension, possible statements were phrased following recommendations for item construction by Bandura (2006) for measuring student-teacher self-efficacy. A total of 49 items were constructed consistent with the adopted definition of teaching selfefficacy. The item distribution is given in Table 1, below.

Table 1 Item Distribution to Dimensions of the Teaching Self-efficacy Scale

\begin{tabular}{|c|r|}
\hline Dimension & \multicolumn{1}{|c|}{ Items } \\
\hline Efficacy for classroom instruction & $1,8,12,14,20,23,26,32,39$ \\
\hline Efficacy for student engagement & $2,9,16,21,27,31,35,40$ \\
\hline Efficacy for classroom management & $3,10,13,22,25,28$ \\
\hline Efficacy for social interaction & $4,11,17,19,24,30,36$ \\
\hline Efficacy for coping with changes and challenges & $6,29,37$ \\
\hline Efficacy for creating a positive school climate & $7,15,34,38,41$ \\
\hline Efficacy for adapting education to students' needs & $5,18,33,42$ \\
\hline
\end{tabular}

As suggested by Pajares, Hartley and Valiante (2001), an efficacy scale with the 0-100 response format is a strong predictor of performance. Accordingly, a Likert-type response format was adopted in which participants were asked to rate how confident they were in their ability to engage in specific practices related to teaching (e.g., I

\section{0}




\section{Number 55, November ,2014}

think I can encourage my students to express their ideas in class) by indicating a degree of confidence ranging in 10-unit intervals from 0 ("Cannot do at all"); through intermediate degrees of assurance, 50 ("Moderately can do"); to complete assurance, 100 ("Highly certain can $\left.d o^{\prime \prime}\right)$.

The TSS was tested on a sample of 45 EFL student teachers at Faculty of Education, Suez University, in order to collect students' comments on the readability and clarity of the statements of the scale. Accordingly, items that were ambiguous were discarded or rewritten. Moreover, items where most people were giving the same score were eliminated as they did not differentiate among respondents. Based on item-total correlation analysis, three items were discarded due to low item-total correlation $(r<0.15)$. The final number of items was 42. Scores on the TSS could range from 0 (the minimal score) to 420 (the maximal score). Participants with higher scores on the TSS scale were more confident in their ability compared to those with lower scores.

For face validity, the TSS was reviewed by some specialists working in the field of TEFL and educational psychology who recommended modifications regarding the language of some items. In order to further test the validity of the TSS, criterion-related validity was examined by assessing the correlation of this new measure to another measure of teaching self-efficacy. A group of EFL students at Faculty of Education, Suez University, were asked to respond not only to the TSS, but also to Bandura's (2006) Teacher Self-Efficacy Scale. Total scores on the TSS were positively related to total scores on Bandura's Scale (Pearson's Coefficient of correlation was 0.743 , significant at the 0.05 level). Moreover, discriminant validity of the TSS was measured by comparing students' scores on it to their scores on a survey testing the presumably negatively related and conceptually distant construct of work alienation, defined in terms of "the extent to which individuals fail to experience intrinsic pride or meaning in their work" (Forsyth \& Hoy, 1978, p. 85). Results indicated that teaching self-efficacy, as measured by the TSS, was significantly negatively related to work alienation, as measured by Forsyth and Hoy's work alienation index. Pearson's Coefficient of correlation was (-0.829), significant at the 0.01 level.

To insure reliability for the TSS, a group of EFL student teachers at Faculty of Education, Suez University, performed the TSS twice with a two-week interval. The two administrations were correlated using Pearson's Coefficient of correlation. The correlation coefficient was 0.801 (significant at the 0.01 level). Moreover, the split-half method was employed. The scale was randomly divided into two equivalent halves and Pearson's coefficient of correlation for these half-tests was

\section{1}


0.862 (significant at the 0.01 level). This coefficient had to be adjusted so that it could be interpreted as full-test reliability. This adjustment was accomplished by using the Spearman-Brown Prophecy formula (Brown, 1996, p. 195). Full-test reliability was 0.926.

Additionally, internal consistency reliability for the scores on the scale and its sub-scales (dimensions) was estimated using Cronbach's coefficient, alpha. Reliability coefficients for the subscales were 0.821 for efficacy for classroom instruction, 0.702 for efficacy for student engagement, 0.897 for efficacy for classroom management, 0.914 for efficacy for social interaction, 0.796 for efficacy for coping with changes and challenges, 0.887 for efficacy for creating a positive school climate, and 0.724 for efficacy for adapting education to students' needs. All coefficients were significant at the 0.01 level.

\section{- Variables}

The study included an independent variable (vlogging) and a dependent variable (teaching self-efficacy).

\section{- Procedures}

\section{- Volunteering}

In this stage, the researcher asked for who would participate in the experimental group. Twelve students agreed to be in the experimental group. The little number of volunteers might be due to the nature of vlogs and the need for having the participant videotape him/herself and publish the videos on the Internet.

\section{- Pretesting}

After identifying the participants in the experimental group, all students were pretested on teaching self-efficacy using the scale devised by the researcher. Based on the result of the pretest, an equivalent control group (consisting of 12 students) was identified among the rest of the class. Mann Whitney U Test of the pretest did not indicate a significant difference between the means of scores of the experimental and control groups $(U=67.00 ; p>0.05)$. This confirmed that the two groups were equivalent. The results of the Mann Whitney $U$ Test of pretests of both groups are summarized in Table 2, below.

Table 2 Mann Whitney U Test for the Differences between the Experimental and Control Groups on the Teaching Self-efficacy Pretest

\begin{tabular}{|c|c|c|c|c|c|}
\hline Group & $\mathrm{N}$ & Mean Rank & Sum of Ranks & Mann-Whitney U & Significance \\
\hline Control & 12 & 12.920 & 155.000 & 67.000 & 0.773 \\
\cline { 1 - 4 } Experimental & 12 & 12.080 & 145.000 & & \\
\hline Total & 24 & & & & \\
\hline
\end{tabular}

- Training

As confirmed by Gunelius (2012), jumping into the world of vlogging is not something one should do without planning. Therefore, three

\section{2}


training sessions were held with the participants of the experimental group. During these sessions, participants were trained in how to record a video using a mobile camera, a digital camera, or a tablet. They were also trained in how to create a vlog, upload videos to a vlog, comment on videos on a vlog, as well as search for videos on the Internet.

Different vlogging hosting services (such as MySpace, YouTube, Qik, Skype, Vimeo, Viddler \& Google Video) were discussed. With the participants, YouTube was chosen to host the vlog of the group. YouTube was chosen because it: (1) is the biggest and most popular online video uploading and sharing site, (2) is easy to use, (3) uses a video player that works well, (4) requires no cost for uploading video clips and (5) enables users to tag their videos and share them easily on other sites (e.g., Twitter, Facebook, etc.). Together, a vlog for the whole group was created on YouTube and its password was distributed to all participants in the experimental group so that they would use it for uploading videos to the vlog as well as comment on each other's videos.

\section{- Treatment}

The experiment of this study was a part of the ELT Methodology course studied by fourth-year EFL student teachers. During a whole term, each participant in the experimental group was required to upload at least three video clips for him/her while teaching authentic, in-class activities during Teaching Practice. Some recommendations were given to students such as: (1) pairing up with a classmate when possible so that he/she could help with the technical aspect of the video recording while the participant is teaching, (2) wearing clothing without checks, lines or busy patterns, (3) creating multiple video clips and choosing the one the participant is most satisfied with and (4) making a back-up copy of the video before submitting it.

The participant had to upload the video to the group vlog accompanied by his/her reflection on his/her teaching performance. Other participants would comment on their group members' videos. The comments would be about the strengths and weaknesses as well as proposed suggestions to improve the participant's performance as a teacher in the video. In this respect, each participant had to comment on at least ten videos of his/her colleagues. The researcher provided the participants with a teaching performance evaluation rubric to help them in evaluating each others as teachers. The participant in the video also had the chance to reply to his/her colleagues' comments and/or reflect on his/her clip, focusing on how he/she could improve.

As confirmed by Pianta, Mashburn, Downer, Hamre and Justice (2008),effective teacher professional development requires

\section{3}


opportunities for teachers to watch high quality teaching and receive regular feedback on their own teaching practice. Therefore, participants were also allowed to search for and share videos of model teaching available on the Internet, either as separate posts or in their comments on other posts. The researcher also participated in commenting on the posts and engaged in rich discussions with the participants about the teaching performance in the videos as well as the comments of the viewers.

\section{- Posttesting}

After the experiment, the two groups were posttested on teaching self-efficacy with the same scale used in the pretest.

\section{- Result}

Mann Whitney $U$ Test of the posttest indicated a statistically significant difference between the means of scores of the control and experimental groups on teaching self-efficacy in favor of the experimental group $(U=33.50 ; p<0.05)$. See Table 3, below.

Table 3 Mann Whitney U Test for the Differences between the Experimental and Control Groups on the Teaching Self-efficacy Posttest

\begin{tabular}{|c|c|c|c|c|c|}
\hline Group & N & Mean Rank & Sum of Ranks & Mann-Whitney U & Significance \\
\hline Control & 12 & 9.290 & 111.500 & 33.500 & 0.026 \\
\cline { 1 - 4 } Experimental & 12 & 15.710 & 188.500 & & \\
\cline { 1 - 4 } Total & 24 & & & & \\
\hline
\end{tabular}

- Discussion of the Result

The purpose of the present study was to investigate the effect of vlogging on EFL student teachers' teaching self-efficacy. The hypothesis of the present study was that there would be a statistically significant difference $(\alpha \leq 0.05)$ in the fourth-year EFL student teachers' teaching self-efficacy between the experimental group and the control group in favor of the experimental group. In order to test this hypothesis, teaching self-efficacy posttest mean scores of the two groups were compared using Mann Whitney U Test. This comparison revealed a statistically significant difference in favor of the experimental group. Based on this result, the researcher accepted the hypothesis of the study and concluded that vlogging had a significant effect on the teaching self-efficacy of EFL student teachers.

As noted earlier, the area regarding the effect of vlogging on teachers' teaching self-efficacy has not been addressed. However, the result of this study is supported by prior literature in the field of teaching self-efficacy; i.e., there is some evidence that some characteristics of vlogging may lead to enhancing teaching selfefficacy. The first of these characteristics is that the vlog is a web tool. In this respect, some studies found that computer-assisted learning and

\section{4}


communicating electronically can enhance general self efficacy (Ruiz, Smith, van Zuilen, Williams \& Mintzer, 2006; Zheng, McAlack, Wilmes, Kohler-Evans \& Williamson, 2009) and teaching self efficacy (Heo, 2011; Seo, Templeton \& Pellegrino, 2008). Another characteristic of vlogs is that they are a form of blogs. Concerning this issue, a number of studies found that blogging is an effective tool in developing teaching self efficacy (e.g., Avci \& Askar, 2012; Stevens \& Harris, 2010). A further characteristic of vlogs is that their medium is video. For this issue, some studies confirmed the potential of using videos to enhance general self efficacy (Barak, Ashkar \& Dori, 2011; Liu, Lin, Jian \& Liou, 2012) as well as teaching self efficacy (Annetta, Frazier, Folta, Holmes, Lamb \& Cheng, 2013; Jamil, 2012; Karsenti \& Collin, 2011; Sang, Valcke, van Braak, Zhu, Tondeur \& Yu, 2012).

Another explanation for the result of the present study is that participants were required to reflect on their teaching performance when they posted their recorded videos to the vlog. This reflection might have improved their teaching self-efficacy as found by Yost (2006), Runhaar, Sanders and Yang (2010) and Tan (2013). This was confirmed earlier by Bandura (1986) who considered self-reflection as an important personal attribute that contributes to one's ability to positively alter his/her own thinking and behavior.

A further explanation for the result of the present study is that student teachers might have benefited from peer interaction in vlogging. This benefit seems to be two-fold. First, participants might have benefited from reading their peers' comments regarding their teaching performance. This explanation agrees with the results of some studies which found that interactions with peers (Wingfield, Nath, Henry, Tyson \& Hutchinson, 2000) and group discussions (Liaw, 2009) improved teaching self-efficacy. Second, participants might have benefited from the behavior of giving comments to their peers regarding these peers' teaching performance. This explanation agrees with the study of Morris and Nunnery (1993) who found that teachers felt that collegiality (extent of teachers' belief that they work with and influence their peers to improve teaching and learning in their schools) enhanced their sense of teaching-efficacy. A final explanation for the result of the present study is that while vlogging, participants watched and shared videos of good teaching practices available on the Internet. This might allowed them, as pre-service teachers, to anticipate actual classroom situations so they could better prepare for them.

Despite the success of vlogging in improving teaching self-efficacy, there were a number of challenges in the study. These challenges included time constraints, discomfort with recording oneself, and some

\section{5}




\section{Number 55, November,2014}

technological and logistical challenges. In some cases, such drawbacks caused students to either post late or miss one or more posts. These are largely consistent with Hung's (2011) findings. He mentioned that the affective barrier is intrinsic to vlogs in part because posting video of oneself in the public sphere is more face-threatening than posting written work.

\section{- Recommendations}

In light of the results of the present study, the following recommendations seem pertinent.

- Vlogs should be included in EFL Teaching Practice.

- More attention should be given to the development of teaching selfefficacy of student teachers.

- Student teachers should be encouraged to use Internet resources to enhance their teaching.

- Student teachers should be encouraged to engage in peer and group discussions about each other's teaching performance.

- Suggestions for Further Research The following topics seem worth attempting:

- investigating the effect of vlogs on EFL students' listening and speaking skills

- investigating students' and teachers' attitudes towards the use of vlogs in learning, teaching and assessment

- investigating the effect of photo blogs (plogs) on EFL pupils' vocabulary development

- investigating the effect of other Web 2.0 tools (e.g., wikis, whiteboards, plogs, etc.) on students' learning

- References

- Abbott, D. (2010). Experiencing creative self-efficacy: A case study approach to understand creativity in blogging. Journal of Media \& Communication Studies, 2(8), 170-175.

- Abdel Aziz, A. (2010). The effectiveness of an in-service training program based on the teacher as scientist (TAS) approach in the development of scientific concepts \& some self-efficacy requirements of Science teachers at the primary stage \& the performance of their pupils. Unpublished Ph.D. dissertation, Institute of Educational Studies, Cairo University.

- Abdel Rahman, I. (2012). A program based on self-regulated learning strategies for developing performances of the thinking teaching \& self-efficacy among mathematics section students in

\section{6}


faculties of education. Unpublished Ph.D. dissertation, Faculty of Education, Port Said University.

- Agbaria, Q. (2013). Self-efficacy \& participation in choosing the teaching profession as predictors of academic motivation among Arab student's girls. Australian Journal of Teacher Education, 38(3), 75-91.

- Al-Aidi, A. (2011). The relationships between teacher job satisfaction in primary schools, teacher self-efficacy \& pupil academic achievement. Unpublished M. Ed. Thesis, Institute of Educational Studies, Cairo University.

- Ali, A. (2011). The effectiveness of metacognitive training program to develop academic, occupational \& social self efficacy for students in New Valley Faculty of Education. Unpublished Ph.D. dissertation, New Valley Faculty of Education, Assiut University.

- Al-Iraki, R. (2014). The effectiveness of suggested electronic training program on the web in developing thinking skills, cognitive achievement \& self efficacy for the computer teacher student. Unpublished Ph.D. dissertation, Faculty of Specific Education, Mansoura University.

- Annetta, L., Frazier, W., Folta, E., Holmes, S., Lamb, R. \& Cheng, M. (2013). Science teacher efficacy \& extrinsic factors toward professional development using video games in a design-based research model: The next generation of STEM learning. Journal of Science Education \& Technology, 22(1), 47-61.

- Avci, U. \& Askar, P. (2012). The comparison of the opinions of the university students on the usage of blog \& wiki for their courses. Educational Technology \& Society, 15(2), 194-205.

- Baker, P. (2005). Managing student behavior: How ready are teachers to meet the challenge? American Secondary Education, 33(3) 51-64.

- Balaji, M. \& Chakrabarti, D. (2010). Student interactions in online discussion forum: Empirical research from 'Media Richness Theory' perspective. Journal of Interactive Online Learning, 9(1), 1-22.

- Balam, E. (2006). Professors' teaching effectiveness in relation to self-efficacy Graduate Faculty of beliefs \& perceptions of student rating myths. Ph.D. dissertation, Graduate Faculty, Auburn University, USA.

- Bandura, A. (1977). Self-efficacy: Toward a unifying theory of behavioral change. Psychological Review, 84, 191-215.

- Bandura, A. (1986). Social foundations of thought \& action: A social cognitive theory. Englewood Cliffs, NJ: Prentice-Hall.

\section{7}


- Bandura, A. (1993). Perceived self-efficacy in cognitive development \& functioning. Educational Psychologist, 28(2), 117148.

- Bandura, A. (1997). Self-efficacy: The exercise of control. New York: W. H. Freeman.

- Bandura, A. (2000). Self-efficacy: The foundation of agency. In W. Perrig \& A. Gorb (Eds.), Control of human behavior, mental processes \& consciousness (pp. 16-33). Mahwah, NJ: Lawrence Erlbaum.

- Bandura, A. (2006). Guide for constructing self-efficacy scale. In F. Pajares \& T. Urdan (Eds.), Self-efficacy beliefs of adolescents (pp. 307-337). Connecticut: Information Age Publishing.

- Bandura, A. (2012). On the functional properties of perceived selfefficacy revisited. Journal of Management, 38(1), 9-44.

- Bangs, J. \& Frost, D. (2012). Teacher self-efficacy, voice \& leadership: Towards a policy framework for Education International. Brussels: Education International.

- Barak, M., Ashkar, T. \& Dori, Y. (2011). Learning Science via animated movies: Its effect on students' thinking \& motivation. Computers \& Education, 56(3), 839-846.

- Barge, J. (October 17, 2012). Teaching kids to have self-efficacy. Santa Monica Daily Press. Retrieved November 15, 2013, from http://smdp.com/teaching-kids-to-have-self-efficacy/113303.

- Belek, B. (2013). I believe it can change the way things are. Diemen, the Netherlands: AMB Press.

- Biel, J. \& Gatica-Perez, D. (2010). Voices of vlogging. Paper presented at the $4^{\text {th }}$ International AAAI Conference on Weblogs \& Social Media, Washington, DC, May 23-26, 2010.

- Biggs, J. (2003). Teaching for quality learning at university ( $2^{\text {nd }}$ ed.). Buckingham: Open University Press.

- Bilbao, J., Bravo, E., García, O., Varela, C., González, P., Baro, I. \& Rodríguez, M. (2009). Powerful tool as a complement to the traditional resources on a course: Video podcast. Paper presented at the $14^{\text {th }}$ WSEAS International Conference on Applied Mathematics, Puerto De La Cruz, Spain, December 14-16, 2009.

- Biocca, F., Harms, C. \& Burgoon, J. (2003). Towards a more robust theory \& measure of social presence: Review \& suggested criteria. Presence: Teleoperators \& Virtual Environments, 12(5), 456-480.

\section{8}




\section{Number 55, November ,2014}

- Blackall, L. (2009). Using collaborative video for e-learning. In S. Mishra (Ed.), E-learning (pp. 76-79). New Delhi: Indira Gandhi National Open University.

- Bloch, J. (2007). Abdullah's blogging: A generation 1.5 student enters the blogosphere. Language Learning \& Technology, 11(2), 128-141.

- Brazburg, J. (2007). Ready for your close up? Create \& post a video blog with ease. Technology \& Learning, 27(6), 26-27.

- Brouwers, A. \& Tomic, W. (2003). A test of the factorial validity of the teacher efficacy scale. Research in Education, 69, 67-80.

- Brown, J. (1996). Testing in language programs. New Jersey: Prentice Hall.

- Burton, J., Bamberry, N. \& Harris-Boundy, J. (2005). Developing personal teaching efficacy in new teachers in university settings. Academy of Management Learning \& Education, 4(2), 160-173.

- Chambers, S., Henson, R. \& Sienty, S. (2001). Personality types \& teaching efficacy as predictors of classroom control orientation in beginning teachers. Paper presented at the Annual Meeting of the Southwest Educational Research Association, New Orleans, LA , February 1-3, 2001.

- Chan, W., Chi, S. \& Chen, I. (2011). Video podcasting in language learning: Students' usage \& perceptions. Paper presented at the $4^{\text {th }}$ International Conference on Education \& New Learning Technologies, Barcelona, Spain, July 2-4, 2012.

- Chen, Y. (2008). Modeling the determinants of Internet use. Computers \& Education, 51(2), 545-558.

- Considine, D., Horton, J. \& Moorman, G. (2009). Teaching \& reading the millennial generation through media literacy. Journal of Adolescent \& Adult Literacy, 52(6), 471-481.

- Curts, J., Tanguma, J. \& Peña, C. (2008). Predictors of Hispanic school teachers' self-efficacy in the pedagogical uses of technology. Computers in the Schools: Interdisciplinary Journal of Practice, Theory \& Applied Research, 25(1-2), 48-63.

- Daft, R. \& Lengel, R. (1984). Information richness: A new approach to managerial behavior \& organizational design. In B. Straw \& L. Cummings (Eds.), Research in organizational behavior (pp. 191233). Greenwich, CT: JAI Press.

- Daft, R. \& Lengel, R. (1986). Organizational information requirements, media richness \& structural design. Management Science, 32(5), 554-571.

\section{9}




\section{Number 55, November ,2014}

- Davis, C., Wright, V., Coleman, G. \& MacCall, S. (2007). Blogging Self-efficacy: Do Age Group \& Experience Really Matter? Retrieved May 15, 2013 from http://www.riversoflearning.com/clay/pubs/Necc-davis-blogging-wcoversheet.pdf.

- Dean, K. (2013). Blogging + Video = Vlogging. Retrieved May 16, 2013 from http://archive.wired.com/entertainment/music/news/2005/07/68171?c urrentPage $=$ all.

- DeChenne, S., Enochs, L. \& Needham, M. (2012). Science, technology, engineering \& mathematics graduate teaching assistants teaching self-efficacy. Journal of the Scholarship of Teaching \& Learning, 12(4), 102-123.

- Dellinger, A., Bobbett, J., Olivier, D. \& Ellett, C. (2008). Measuring teachers' self efficacy beliefs: Development \& the use of the TEBSSelf. Teaching \& Teacher Education, 24(3), 751-766.

- Demirel, M. (2009). Self-efficacy beliefs of elementary teachers \& school principals for character education. H. U. Journal of Education, 37, 36-49.

- Dhatt, H. \& Tiwari, G. (2013). Development of self-efficacy scale of B. Ed. student-teachers. European Academic Research, 1(9), 25602573.

- Diaz, V. (2010). Web 2.0 \& emerging technologies in online learning. New Directions for Community Colleges, 150, 57-66.

- Efimova, L. \& Fiedler, S. (2004). Learning webs: Learning in weblog networks. In P. Kommers, P. Isaias \& M. Nunes (Eds.), Proceedings of the IADIS International Conference on Web Based Communities, Lisbon, March 24-26, 2004. Lisbon: IADIS Press.

- El-Sweedy, N. (2012). The effect of a suggested program on developing beliefs \& teaching skills related to writing among EFL prospective teachers. Unpublished Ph.D. dissertation, Faculty of Education, Benha University.

- Felix, L. \& Stolarz, D. (2006). Hands-on guide to video blogging \& podcasting. Burligton, MA: Focal Press.

- Ferdig, R. \& Trammell, K. (2004). Content delivery in the 'blogosphere'. THE Journal, 31(7), 12-15.

- Fisler, J. \& Firestone, W. (2006). Teacher learning in a schooluniversity partnership: Exploring the role of social trust \& teaching efficacy beliefs. Teachers College Record, 108(6), 1155-1185.

- Forsyth, P. \& Hoy, W. (1978). Isolation \& alienation in educational organizations. Educational Administration Quarterly, 14(1), 80-96.

\section{0}




\section{Number 55, November ,2014}

- Friedman, I. \& Kass. E. (2002). Teacher self-efficacy: A classroomorganization conceptualization. Teaching \& Teacher Education, $18(6), 675-686$.

- Frobenius, M. (2011). Beginning a monologue: The opening sequence of video blogs. Journal of Pragmatics 43(3), 814-827.

- Gale, E. \& Kung, S. (2009). Teaching a foreign language with video podcast assignments: Examples from an American Sign Language course. Educause Quarterly, 32(4). Retrieved January 23, 2014 from http://www.educause.edu/ero/article/teaching-foreign-languagevideo-podcast -assignments-examples-american-sign-languagecourse.

- Gao, W., Tian, Y., Huang, T. \& Yang, Q. (2010). Vlogging: A survey of videoblogging technology on the Web. ACM Computing Surveys, 42(4), 1-57.

- Garvis, S. \& Pendergast, D. (2011). An investigation of early childhood teacher self-efficacy beliefs in the teaching of Arts Education. International Journal of Education \& the Arts, 12(9). Retrieved November 29, 2013 from http://www.ijea.org/v12n9/.

- Gerberry, C. (2009). Participation in cooperative groups \& selfefficacy beliefs of females in mathematics. Unpublished Ph.D. dissertation, Purdue University.

- Giallo, R. \& Little, E. (2003). Classroom behavior problems: The relationship between preparedness, classroom experiences \& selfefficacy in graduate \& student teachers. Australian Journal of Educational \& Developmental Psychology, 3, 21-34.

- Gibson, S. \& Dembo, M. (1984). Teacher efficacy: A construct validation. Journal of Educational Psychology, 76(4), 569-582.

- Goddard, R., Hoy, W. \& Woolfolk Hoy, A. (2000). Collective teacher efficacy: Its meaning, measure \& impact on student achievement. American Educational Research Journal, 37(2), 479507.

- Godwin-Jones, R. (2006). Emerging technologies. Tag clouds in the blogosphere: Electronic literacy \& social networking. Language Learning \& Technology, 10(2), 8-15.

- Griffith, M. \& Papacharissi, Z. (2010). Looking for you: An analysis of video blogs. First Monday, 15(1). Retrieved June 14, 2013 from http://firstmonday.org/ojs/index.php/fm/article/viewArticle/2769/243 $\underline{0 .}$

- Gronstedt, A. (2007). The changing face of workplace learning. $T+D, 61(1), 20-24$. 
- Guenter, C. (2008). Understanding Web 2.0 technologies: Using wikis, blogs \& podcasting. Paper presented at MERLOT International Conference, Minneapolis, MN, August 7-10, 2008.

- Gunelius, S. (2012). Blogging all-in-one for dummies ( $2^{\text {nd }}$ ed.). New Jersey: John Wiley \& Sons.

- Guo, Y., Piasta, S., Justice, L. \& Kaderavek, J. (2010). Relations among preschool teachers' self-efficacy, classroom quality \& children's language \& literacy gains. Teaching \& Teacher Education, 26(4), 1094-1103.

- Guskey, T. \& Passaro, P. (1994). Teacher efficacy: A study of construct dimensions. American Educational Research Journal, 31(3), 627-643.

- Haight, K. (2011). The Adoption \& Integration of Technology within the Classroom: Teacher Self-Efficacy Beliefs. ERIC Document Reproduction Service No. ED 526375.

- Harley, D. \& Fitzpatrick, G. (2009). Creating a conversational context through video blogging: A case study of Geriatric1927. Computers in Human Behavior, 25(3), 679-689.

- Harris, D. (2008). Blogging 100 success secrets: 100 most asked questions on building, optimizing, publishing, marketing \& how to make money with blogs. Harlow, UK: Pearson Education.

- Hassab Allah, A. (2012). Future career anxiety \& its relation to personality traits \& academic self-efficacy of a sample of College of Education students, Minia University. Unpublished M. Ed. Thesis, Faculty of Education, Minia University.

- Haubold, A. \& Kender, J. (2007). Introduction of video journals \& archives in the classroom. Paper presented at ASEE Annual Conference \& Exhibition, Honolulu, HI, June 24-27, 2007.

- Henson, R. (2001). Teacher self-efficacy: Substantive implications \& measurement dilemmas. Paper presented at the Annual Meeting of the Educational Research Exchange, College Station, TX, January 26, 2001.

- Henson, R., Kogan, L. \& Vacha-Haase, T. (2001). A reliability generalization study of the teacher efficacy scale \& related instruments. Educational \& Psychological Measurement, 61(3), 404420.

- Heo, M. (2011). Improving technology competency \& disposition of beginning pre-service teachers with digital storytelling. Journal of Educational Multimedia \& Hypermedia, 20(1), 61-81.

- Hines, M. (2008). The interactive effects of race \& teacher self efficacy on the achievement gap in school. International Electronic

\section{2}

Journal of Arabic Studies in Education \& Psychology (ASEP) 
Journal for Leadership in Learning, 12(11). Retrieved November 23, 2013

from http://iejll.journalhosting.ucalgary.ca/iejll/index.php/ijll/article/view/ $555 / 217$.

- Hung, S. (2011). Pedagogical applications of vlogs: An investigation into ESP learners' perceptions. British Journal of Educational Technology, 42(5), 736-746.

- Huntington, H. \& Worrell, T. (2013). Information communication technologies in the classroom: Expanding TAM to examine instructor acceptance \& use. Journal of Educational Multimedia \& Hypermedia, 22(2), 147-164.

- Jamil, F. (2012). MyTeachingPartner: A Professional Development Intervention for Teacher Self-efficacy. ERIC Document Reproduction Service No. ED 530450.

- Johnson, B. (2005). Someone call Karl Marx: The means of production is in the hands of the masses \& a revolution is under way. Maclean's, 118(51), 56-60.

- Jones, L. (2007). The student-centered classroom. New York: Cambridge University Press.

- Kaminsky, M. (2010). Naked lens: Video blogging \& video journaling to reclaim the YOU in YouTube. Brooklyn: Organik Media.

- Kang, X., Zhang, H., Jiang, G., Chen, H., Meng, X. \& Yoshihira, K. (2010). Understanding Internet video sharing site workload: A view from data center design. Journal of Visual Communication \& Image Representation, 21, 129-138.

- Karkoski, K. (2013). How to Video Blog. Retrieved May 13, 2014 from http://www.howtodothings.com/computers/a3803-how-tovideo-blog.html.

- Karsenti, T. \& Collin, S. (2011). The impact of online teaching videos on Canadian pre-service teachers. Campus-Wide Information Systems, 28(3), 195-204.

- Kaur, K. \& Kaur, P. (2013). Relationship between self-efficacy \& teacher motivation of secondary school teachers of Punjab. Indian Streams Research Journal, 3(9), 1-3.

- Kay, R. \& Edwards, J. (2010). Evaluating the use of instructional video podcasts for middle school mathematics students. In Proceedings of World Conference on Educational Multimedia, Hypermedia \& Telecommunications 2010 (pp. 3626-3629). Chesapeake, VA: AACE.

\section{3}


- Kaye, L. \& Brewer, G. (2013). Teacher \& student-focused approaches: Influence of learning approach \& self-efficacy in a psychology postgraduate sample. Psychology Learning \& Teaching, 12(1), 12-19.

- Kim, E. (2009). Beyond language barriers: Teaching self-efficacy among East Asian international teaching assistants. International Journal of Teaching \& Learning in Higher Education, 21(2), 171180.

- Knobloch, N. \& Whittington, M. (2002). Novice teachers' perception of support, teacher preparation quality \& student teaching experience related to teacher efficacy. Journal of Vocational Education Research, 27(3), 331-341.

- Labone, E. (2004). Teacher efficacy: Maturing the construct through research in alternative paradigms. Teaching \& Teacher Education, 20(4), 341-359.

- Lacina, J. (2008). Learning English with iPods. Childhood Education, 84(4), 247-249.

- Leithwood, K. (2006). Teacher working conditions that matter: Evidence for change. Toronto: Elementary Teachers' Federation of Ontario.

- Liaw, E. (2009). Teacher efficacy of pre-service teachers in Taiwan: The influence of classroom teaching \& group discussions. Teaching \& Teacher Education, 25(1), 176-180.

- Liaw, S. (2008). Investigating students' perceived satisfaction, behavioral intention, \& effectiveness of e-learning: A case study of the blackboard system. Computers \& Education, 51(2), 864-873.

- Liu, E., Lin, C., Jian, P. \& Liou, P. (2012). The dynamics of motivation \& learning strategy in a creativity-supporting learning environment in higher education. The Turkish Online Journal of Educational Technology, 11(1), 172-180.

- Llamas-Nistal, M., Caeiro-Rodríguez, M. \& Castro, M. (2011). Use of e-learning functionalities \& standards: The Spanish case. IEEE Transactions on Education, 54(4), 540-549.

- Loreman, T., Sharma, U. \& Forlin, C. (2013). Do pre-service teachers feel ready to teach in inclusive classrooms? A four country study of teaching self-efficacy. Australian Journal of Teacher Education, 38(1), 27-44.

- Lumpe, A. \& Chambers, E. (2001). Assessing teachers' context beliefs about technology use. Journal of Research on Technology in Education, 34(1), 93-107.

\section{4}


- Mack, S. (2009). How to Make a Quick \& Effective Video Blog. Retrieved December 23, 2013 from http://impactvideoproduction.com/articles/038-createvideoblog.pdf.

- Mackey, R. (2005, December 11). Video podcasts. The New York Times. Retrieved January 17, 2013, from http://www.nytimes.com/2005/12/11/magazine/11ideas section415.html? $\mathrm{r}=0$

- Maigo, L. \& Mei-yan, L. (2010). The study of teachers' task values \& self-efficacy on their commitment \& effectiveness for technologyinstruction integration. US-China Education Review, 7(5), 1-11.

- Margolis, H. \& McCabe, P. (2006). Improving self-efficacy \& motivation: What to do, what to say. Intervention in School \& Clinic, 41(4), 218-227.

- Marzano, R. (2012). Art \& science of teaching: Teaching selfefficacy with personal projects. Educational Leadership, 69(8), 8687.

- Matheson, D. (2004). Weblogs \& the epistemology of the news: Some trends in online journalism. New Media \& Society, 6(4), 443468.

- Milbrath, Y. \& Kinzie, M. (2000). Computer technology training for prospective teachers: Computer attitudes \& perceived self-efficacy. Journal of Technology \& Teacher Education, 8(4), 373-396.

- Milliken, M., O’Donnell, S., Gibson, K. \& Daniels, B. (2012). Older citizens \& video communications: A case study. Journal of Community Informatics, 8(1). Retrieved February 1, 2014 from http://ci-journal.net/index.php/ciej/article/view/697/829.

- Mohammed, A. (2010). Delay of academic gratification \& its relationship to both goal orientation \& self-efficacy among Zagazig University students. Unpublished M. Ed. Thesis, Faculty of Education, Zagazig University.

- Mohammed, H. (1997). Job satisfaction among general \& industrial secondary school teachers \& relation to self-efficacy \& burnout. Unpublished M. Ed. Thesis, Faculty of Education, Ain Shams University.

- Molyneaux, H., Gibson, K., O'Donnell, S. \& Singer, J. (2008). New visual media \& gender: A content, visual \& audience analysis of YouTube vlogs. Paper presented at the International Communication Association Annual Conference, Montreal, Quebec, Canada, May 22-26, 2008.

\section{5}




\section{Number 55, November ,2014}

- Morales, C., Knezek, G. \& Christensen, R. (2008). Self-efficacy ratings of technology proficiency among teachers in Mexico \& Texas. Computers in the Schools, 25(1), 126-144.

- Morris, V. \& Nunnery, J. (1993). Teacher Empowerment in a Professional Development School Collaborative: Pilot Assessment. ERIC Document Reproduction Service No. ED 368678.

- Mosenson, A. \& Johnson, J. (2008). Instructional strategies \& resources: Exploring the use of technology. Journal of Family Consumer Sciences Education, 26(3), 17-35.

- Niederhauser, D. \& Perkmen, S. (2008). Validation of the intrapersonal technology integration scale: Assessing the influence of intrapersonal factors that influence technology integration. Computers in the Schools, 25(1-2), 98-111.

- Okonkwo, U. (2010). Luxury online: Styles, systems, strategies. Hampshire: Palgrave Macmillan.

- Onafowora, L. (2005). Teacher efficacy issues in the practice of novice teachers. Educational Research Quarterly, 28(4), 34-43.

- Orr, B. (2007). Parsing the meaning of Web 2.0. ABA Banking Journal, 99(4), 53-54.

- Overbaugh, R. \& Lu, R. (2008). The impact of a NCLB-EETT funded professional development program on teacher self-efficacy \& resultant implementation. Journal of Research on Technology in Education, 41(1), 43-61.

- Pajares, F., Hartley, J. \& Valiante, G. (2001). Response format in writing self-efficacy assessment: Greater discrimination increases prediction. Measurement \& Evaluation in Counseling \& Development, 33(4), 214-221.

- Pan, S. \& Franklin, T. (2011). In-service teachers' self-efficacy, professional development \& Web 2.0 tools for integration. New Horizons in Education, 59(3), 28-40.

- Papastergiou, M., Gerodimos, V. \& Antoniou, P. (2011). Multimedia blogging in Physical Education: Effects on student knowledge \& ICT self-efficacy. Computers \& Education, 57(3), 1998-2010.

- Parker, C. \& Pfeiffer, S. (2005). Video blogging: Content to the max. IEEE MultiMedia, 12(2), 4-8.

- Pianta, R., Mashburn, A., Downer, J., Hamre, B. \& Justice, L. (2008). Effects of web-mediated professional development resources on teacher-child interactions in pre-kindergarten classrooms. Early Childhood Research Quarterly, 23(4), 431-451.

\section{6}


- Pilkington, E. (2009, July 9). Merriam-Webster releases list of new words to be included in dictionary. The Guardian (London).

- Pintrich, P. \& Schunk, D. (2008). Motivation in education: Theory, research \& applications $\left(3^{\text {rd }}\right.$ ed.). Upper Saddle River, NJ: Pearson Education.

- Prensky, M. (2001). Digital natives, digital immigrants. On the Horizon, 9(5), 1-6.

- Quinn, M. (2007). Assessment \& correlates of teaching self-efficacy in a preschool \& kindergarten teacher population. Unpublished Ph.D. dissertation, Purdue University.

- Reynolds, K. \& Barba, R. (1996). Technology for the teaching \& learning of science. Needham Heights, MA: Allyn \& Bacon.

- Richardson, W. (2010) Blogs, wikis, podcasts \& other powerful web tools for classrooms ( $3^{\text {rd }}$ ed.). California: Corwin Press.

- Rogalla, M. (2004). Future problem solving program coaches' efficacy in teaching for successful intelligence \& their patterns of successful behavior. Roeper Review, 26, 175-176.

- Ruiz, J., Smith, M., van Zuilen, M., Williams, C. \& Mintzer, M. (2006). The educational impact of a computer-based training tutorial on dementia in long-term care for licensed practice nursing students. Gerontology \& Geriatrics Education, 26(3), 67-79.

- Runhaar, P., Sanders, K. \& Yang, H. (2010). Stimulating teachers' reflection \& feedback asking: An interplay of self-efficacy, learning goal orientation \& transformational leadership. Teaching \& Teacher Education, 26(5), 1154-1161.

- Sang, G., Valcke, M., van Braak, J., Zhu, C., Tondeur, J. \& Yu, K. (2012). Challenging science teachers' beliefs \& practices through a video-case-based intervention in china's primary schools. AsiaPacific Journal of Teacher Education, 40(4), 363-378.

- Sankar, K. \& Bouchard, S. (2009). Enterprise Web 2.0 fundamentals. Indianapolis: Cisco Press.

- Scheerens, J. (Ed.). (2010). Teachers' professional development: Europe in international comparison. Luxembourg: European Union.

- Scherbaum, C., Cohen-Charash, Y. \& Kern, M. (2006). Measuring general self-efficacy: A comparison of three measures using item response theory. Educational \& Psychological Measurement, 66(6), 1047-1063.

- Seo, K., Templeton, R. \& Pellegrino, D. (2008). Creating a ripple effect: Incorporating multimedia-assisted project-based learning in teacher education. Theory into Practice, 47(3), 259-265.

\section{7}


- Settlage, J., Southerland, S., Smith, L. \& Ceglie, R. (2009). Constructing a doubt- free teaching self: Self-efficacy, teacher identity \& science instruction within diverse settings. Journal of Research in Science Teaching, 46(1), 102-125.

- Shelley, G. \& Vermaat, M. (2012). Discovering computers: Your interactive guide to the digital world. Boston: Course Technology, Cengage Learning.

- Shih, R. (2010). Blended learning using video-based blogs: Public speaking for English as a Second Language students. Australasian Journal of Educational Technology, 26(6), 883-897.

- Short, J., Williams, E. \& Christie, B. (1976). The social psychology of telecommunications. London: John Wiley.

- Silverman, S. \& Davis, H. (2009). Teacher Efficacy. Retrieved February 23, 2014 from http://www.education.com/reference/article/teacher-efficacy/

- Siwatu, K. (2007). Preservice teachers' culturally responsive teaching self-efficacy \& outcome expectancy beliefs. Teaching \& Teacher Education, 23(7), 1086-1101.

- Skaalvik, E. \& Skaalvik, S. (2007). Dimensions of teacher selfefficacy \& relations with strain factors, perceived collective teacher efficacy \& teacher burnout. Journal of Educational Psychology, 99(3), 611-625.

- Skaalvik, E. \& Skaalvik, S. (2014). Teacher self-efficacy \& perceived autonomy: Relations with teacher engagement, job satisfaction \& emotional exhaustion. Psychological Reports, 114(1), $68-77$.

- Stevens, T. \& Harris, G. (2010). Developing teachers' mathematics knowledge for teaching: Challenges in the implementation \& sustainability of a new MSP. Paper presented at MSP LNC Conference, Washington D.C., January 24-26, 2010.

- Stripling, C., Ricketts, J., Roberts, T. \& Harlin, J. (2008). Preservice agricultural education teachers' sense of teaching self-efficacy. Journal of Agricultural Education, 49(4), 120-130.

- Swan, B., Wolf, K. \& Cano, J. (2011). Changes in teacher selfefficacy from the student teaching experience through the third year of teaching. Journal of Agricultural Education, 52(2), 128-139.

- Sweat-Guy, R. \& Buzzetto-More, N. (2007). Instructor \& student roles in two opposing pedagogies. In N. Buzzetto-More (Ed.). Advanced principles of effective e-learning (pp. 113-131). Santa Rosa: Informing Science Press.

\section{8}


- Tan, J. (2013). Dialoguing written reflections to promote selfefficacy in student teachers. Reflective Practice, 14(6), 814-824.

- Temple, C., Ogle, D., Crawford, A. \& Freppon, P. (2013). All children read: Teaching for literacy in today's diverse classrooms ( $4^{\text {th }}$ ed.). Boston: Pearson.

- Tracey, D. \& Morrow, L. (2012). Lenses on reading: An introduction to theories \& models ( $2^{\text {nd }}$ ed.). New York: Guilford Press.

- Tschannen-Moran, M. \& Woolfolk Hoy, A. (2001). Teacher efficacy: Capturing an elusive construct. Teaching \& Teacher Education, 17(7), 783-805.

- Tschannen-Moran, M. \& Woolfolk Hoy, A. (2007). The differential antecedents of self-efficacy beliefs of novice \& experienced teachers. Teaching \& Teacher Education, 23(6), 944-956.

- United Nations Environment Program (2014). Blog Competition. Retrieved April 10, 2014 from http://www.unep.org/wed/blogcompetition/submission-guidelines.asp\#.U0ok-Kh5OEs.

- Warmbrodt, J., Sheng, H., Hall, R. \& Cao, J. (2010). Understanding the video bloggers' community. International Journal of Virtual Communities \& Social Networking, 2(2), 43-59.

- Watson, G. (2006). Technology professional development: Longterm effects on teacher self-efficacy. Journal of Technology \& Teacher Education, 14(1), 151-165.

- Weller, M., Pegler, C. \& Mason, R. (2005). Use of innovative technologies on an e-learning course. The Internet \& Higher Education, 8, 61-71.

- Wepner, S., Krute, L. \& Jacobs, S. (2009). Alumni mentoring of beginning teachers. SRATE Journal, 18(2), 56-64.

- Wheatley, K. (2005). The case for reconceptualizing teacher efficacy research. Teaching \& Teacher Education, 21(7), 747-766.

- Wheeler, J. \& Knobloch, N. (2006). Relationships of teacher \& program variables to beginning agriculture teachers' sense of efficacy. Paper presented at the National Agricultural Education Research Conference, Charlotte, NC, May 17-19, 2006.

- Winer, D. (2003). What Makes a Weblog a Weblog? Retrieved March 23, 2014 from http://blogs.law.harvard.edu/whatMakesAWeblogAWeblog.

- Wingfield, M., Nath, J., Henry, C., Tyson, E. \& Hutchinson, L. (2000). Professional development site schools: A great place for training elementary language arts preservice teachers. Paper

\section{9}


presented at the Annual Meeting of the American Educational Research Association, New Orleans, LA, May 15, 2000.

- Winter, J. (2012). Social Presence. Retrieved October 23, 2013 from http://etec.ctlt.ubc.ca/510wiki/Social Presence.

- Woolfolk Hoy, A. (2004). Self-efficacy in college teaching. Essays on Teaching Excellence: Toward the Best in the Academy, 15(7), 811.

- Woolfolk Hoy, A. \& Davis, H. (2005). Teacher self-efficacy \& its influence on the achievement of adolescents. In F. Pajares \& T. Urdan (Eds.), Self-efficacy beliefs of adolescents (pp. 117-137). Greenwhich, CT: Information Age Publishing.

- Woolfolk Hoy, A. \& Hoy, W. (2009). Instructional leadership: A research-based guide to learning in schools ( $3^{\text {rd }}$ ed.). Boston: Allyn \& Bacon.

- Woolfolk Hoy, A. \& Spero, R. (2005). Changes in teacher efficacy during the early years of teaching: A comparisons of four measures. Teaching \& Teacher Education, 21(4), 343-356.

- Yeh, Y. (2006). The interactive effects of personal traits \& guided practices on preservice teachers' changes in personal teaching efficacy. British Journal of Educational Technology, 37(4), 513.

- Yoon, J. (2002). Teacher characteristics as predictors of teacherstudent relationships: Stress, negative affect \& self-efficacy. Social Behavior \& Personality, 30, 485-493.

- Yost, D. (2006). Reflection \& self-efficacy: Enhancing the retention of qualified teachers from a teacher education perspective. Teacher Education Quarterly, 33(4), 59-76.

- Young, S. \& Bippus, A. (2008). Assessment of graduate teaching assistant (GTA) training: A case study of a training program \& its impact on GTAs. Communication Teacher, 22(4), 116-129.

- Zheng, R., McAlack, M., Wilmes, B., Kohler-Evans, P. \& Williamson, J. (2009). Effects of multimedia on cognitive load, selfefficacy \& multiple rule-based problem solving. British Journal of Educational Technology, 40(5), 790-803.

\section{潾潾潾潾}

\section{0}

